\title{
INFLUENCES ON SMOKING BEHAVIOUR OF ADOLESCENTS AND YOUNG ADULTS IN A NIGERIAN UNIVERSITY
}

\author{
Olubukola O. Ojo, ${ }^{1}$ Ajibike O. Lawani, ${ }^{1}$ Michael A. Adedigba ${ }^{2}$ and \\ Solomon O. Nwhator ${ }^{2}$ \\ ${ }^{1}$ Department of Educational Foundations and Counselling, ${ }^{2}$ Preventive and Community \\ Dentistry, Obafemi Awolowo University, Ile-Ife, Nigeria.
}

\begin{abstract}
The study investigated whether parenting style, parental level of education and smoking peers have any influence on the smoking behaviour of adolescents and young adults. The participants were students of Obafemi Awolowo University, Ile-Ife, Nigeria. Purposive sampling technique was adopted in the sample selection. Three hundred students who consented participated in the study. A self constructed questionnaire was used to collect the data. The validity of the instrument was determined. The reliability of the instrument was also determined using test retest method. Correlation co-efficient of 0.75 was obtained. This study revealed that there is a significant influence of parenting style on the smoking behaviour of students $(\mathrm{x} 2=36.03, \mathrm{df}=6$, $\mathrm{p} \leq 0.05)$. It also showed that there is a significant relationship between parents' educational attainment and students' smoking behaviour $(\mathrm{x} 2=60.40$, df $=6, \mathrm{p} \leq 0.05)$. Finally, it was revealed that there was a significant influence of peers on smoking behaviour $(\mathrm{x} 2=19.97, \mathrm{df}=2$, $\mathrm{p} \leq 0.05)$.
\end{abstract}

KEY WORDS: Smoking, Behaviour, Parent, Adolescent, University

\section{INTRODUCTION}

The prevalence of smoking among adolescents and young adults has not declined in spite of all preventive efforts as acknowledged by Bothmer, Mattsson and Fridlund (2002). Smoking usually begins in the early teens and puts health at risk in every community. Cigarette advertising also lures adolescents and young adults to start smoking. Nearly all first use occurs in secondary school. It is common for adolescents to feel social pressure in many ways from clothing and music to risky areas such as drugs, sex, and smoking, and they tend to experiment and try out new experiences.
The period of experimentation is usually very dangerous because of accompanying risk, injury or death. Alcohol and cigarettes are gateway drugs because they are usually the first drugs that are used before other drugs are tried out Merril (1994). Furthermore, BlazeTemple and Kai Lo (1992) asserted that alcohol and tobacco were important "gateway" drugs that lead to increased use of other illegal drugs. Most drug use starts during the period of adolescence especially for 'gateway' drugs. Nigerian adolescents have been identified as a major group involved in the use and abuse of drugs (FMOH, 2000).

So many factors have been put

\footnotetext{
* Corresponding Author: Dr. O. O. Ojo, Department of Educational Foundations and Counselling, Obafemi Awolowo University, Ile-Ife, Nigeria. E-mail: oojo@oauife.edu.ng
} 
forward for adolescents' and young adults' engagement in smoking among which are for normal developmental changes, psychological factors, social environment and sexual factors. Under normal developmental changes, influence of peers, the need to conform and direct craving for cigarettes/alcohol use (gateway drugs) have been mentioned. For psychological factors, emotional problems such as low self-esteem, dissatisfaction with life, less social confidence, need for approval, anxiety, restlessness, promiscuity, antisocial and conduct symptoms were identified. Considering social environment, family influences (when adolescents have parents who are unstable and engage in smoking, drug use and drink), role of the media (for instance advertisements for cigarettes, alcohol, portray people who drink and smoke as sexy, manly and sophisticated) have also been mentioned. With respect to sexual factors, typically adolescents who are preoccupied with sex and sexual performance most frequently smoke and use psychoactive drugs. The earlier the age, the more likely dependence will occur.

Karen et. al. (1992) reviewed findings from 27 prospective studies of the onset of cigarette smoking conducted since 1980. Almost 300 measures of predictors of smoking onset were examined, and $74 \%$ of them provided multivariate support for predictors of onset derived from theory and previous empirical findings. Expected relationships were strongly supported for (a) socioeconomic status, with students with compromised status being more likely to try smoking; (b) social bonding variables, particularly peer and school bonding, with less support for family bonding; (c) social learning variables, especially peer smoking and approval, prevalence estimates, and offers/availability, with less consistent support for parent smoking and approval; (d) refusal skills self efficacy; (e) knowledge, attitudes and intentions, with the expected stronger predictions from intentions than from attitudes than from knowledge; and (f) broad indicators of self-esteem. The few investigators who analyzed their data separately by age, gender, or ethnicity found many differences by these factors, though there were too few of them to detect any pattern with confidence. Though the 27 studies are far from perfect, we believe that they confirm the importance of many well-accepted predictors and raise some questions about others. In particular, family smoking, bonding and approval each received unexpectedly low support, It is not clear whether this lack of support reflects reality as it has always been, is due to a changing reality, reflects developmental changes, either in the age of subjects or the stage of onset, or is due to poor measurement and too few tests.

According to Simons-Morton, Haynie, Crump, Eitel, Saylor (2001) social influences can promote or discourage adolescent substance use. The authors surveyed 4,263 sixth- to eighthgrade students to assess the effect of peer and parent influences on adolescent substance use. The authors conducted separate multiple logistic regression analyses for smoking and drinking, controlling for grade, sex, and race. Positive independent associations with smoking and drinking were found for direct peer pressure and associating with problem-behaving friends. Independent negative associations with smoking and drinking were also found for parent involvement, parent expectations, and parent regard. In an analysis of interactions, peer pressure was positively associated with drinking for girls but not for boys and problem-behaving friends 
was positively associated with drinking for both boys and girls. The findings revealed that associating with deviant peers promotes smoking and drinking while authoritative parenting protects against smoking and drinking.

According to Karen (1992) the family unit is the primary source of transmission of basic social, cultural, genetic, and biological factors that may underlie individual differences in smoking. Past researches emphasised the important role that family related variables play in the prediction of various adolescent and young adults' risky behaviours (Hawkins et al., 1992; Kandel, 1996\}. In a study by Borthmer et. al. (2002) investigating the influence of smoking habits of family members on tobacco use by adolescents, the results reveal that smoking habits by relatives, especially siblings influenced tobacco use by adolescents. They also found an association between smoking by adolescents and mother's employment and between the smoking status of girls and family status.

Also much importance is attached to the role that parents play in the behavioural development of their child. According to Darling and Steinberg (1993), parenting is a complex activity that include much specific behaviour that works individually and together to influence child's outcomes. Research on adolescent cigarette smoking has attempted to measure the role of parents in preventing smoking experimentation and uptake. However, aspects of parental influence have often been limited to parental smoking behaviour or antismoking socialization. Only a limited number of studies considered the hypothesis that the influence of parenting on adolescent current cigarette smoking may extend beyond parental behaviour and antismoking socialization to consider broader measures of the parent-child relationship, such as parenting style. (Chassin, Presson, Rose, Sherman, Davis and Gonzalez, 2005)

Parenting style is one of the primary determinants of a child's outcome because parents are the first contact of a child and also their primary role model. This view was supported by the U.S National centre for education statistics (1999) that stressful family environments as well as role modelling of inappropriate behaviour can contribute to the development of risky behaviour. O'Byrne, Haddock and Poston (2002) investigated whether parenting style is an independent risk factor of smoking initiation and experimentation among adolescents, and whether there is a relationship between parenting style and nicotine dependence among smokers. Results from two logistic regression models indicate that although parenting style is not a significant risk factor for smoking experimentation, it is a significant independent risk factor for smoking initiation. Smokers who were more ready to quit had higher parenting style scores than those who were not ready to quit, and smokers who had made a serious quit attempt (an indicator of nicotine addiction) had higher parenting style scores than those who had not made a quit attempt. Moreover, non smokers who reported they would smoke a cigarette if their best friend offered had significantly lower parenting style scores than those who reported they would not smoke a cigarette.

According to Baumrind (1989) four common group of parenting styles exist. They are authoritarian, permissive, authoritative and rejecting/neglecting. Huxley (2005) emphasized that these styles correspond to a balance of love and limits. Love and limits are terms that describe a parent's discipline orientation. Parents who use love as their primary 
style can be described as permissive parents. They consider love to be more important than limits. They also use attachment and bond they share with their children to teach them right from wrong. A lot of time is spent communicating, negotiating and reasoning with the child. It can also be said that they value increasing the child's esteem thus making them to feel special. Parents who adopt limits to be their primary style can be described as authoritarian parent. Such parents consider limits to be more important than love relationship. The use of external control is adopted to teach right from wrong. These parents are also quick to act on a discipline problem. The result of this style of parenting is that the children are usually quick to react and rarely get their parents to negotiate. Such parents place their value on teaching respect and providing structure. Rejecting and neglecting parents have low limits and low love. Low attention is placed on the style of parenting and hence low value is placed on the child. An understanding of certain behaviour exhibited by adolescents is an indication of parental discipline and overall condition in the home.

There are variations in the level and methods adopted by parents in controlling or socializing their children but there is an assumption that the primary role of all parents is to influence, teach and control their children Darling (1999). Authoritative parents are both demanding and responsive. "They monitor and impart clear standards for their children's conduct. They are assertive, but not intrusive and restrictive. Their disciplinary methods are supportive, rather than punitive. They want their children to be assertive as well as socially responsible, and self-regulated as well as cooperative. One key difference between authoritarian and authoritative parenting is in the dimension of psychological control. Both authoritarian and authoritative parents place high demands on their children and expect their children to behave appropriately and obey parental rules. Authoritarian parents, however, also expect their children to accept their judgments, values, and goals without questioning. In contrast, authoritative parents are more open to give and take with their children and make greater use of explanations. Thus, although authoritative and authoritarian parents are equally high in behavioral control, authoritative parents tend to be low in psychological control, while authoritarian parents tend to be high.

While parenting style is widely believed to have significant direct influence on adolescents' decision about smoking, these influences are neither well documented nor well understood in this part of the world especially Nigeria, hence this study.

It has long been recognized that adolescents and young adults do not try cigarettes in a vacuum. Significant others such as friends, classmates, sibling or parents are the most important factors influencing smoking of adolescents and young adults in the society. Problems associated with smoking include failure to fulfil major roles at work, school, or home. Spear and Akers (1988) (e.g. repeated absences; expulsions from school and neglect of duties).Continued smoking and substance use can result in persistent or recurrent social or interpersonal problems (e.g., arguments with peers, siblings or physical fights). Acute intoxication also follows excessive smoking and ingestion of substance resulting in symptoms of disruption of cognitive processes, affect or behaviour. Medical problems are also related to smoking. Most of these medical effects are attributable to 
nicotine chronic toxicity (Alfred et al., 1990). There are also consequences to the community such as economic loss, damage to machinery, ill health and pressure on public health institutions. There is also pressure on the legal, judicial and security services.

In this study it is assumed that peers, parenting style and some other variables like the education of the parents might influence adolescent and young adults smoking behaviour. Education of the parents possibly has bearing with parenting style which then reflects on the children's behaviour. Furthermore, parental level of education might determine the kind of lifestyles parents have and may likely influence adolescents lifestyles also in the mode of social and instrumental competence. Since cigarette is a gateway to other illicit drugs it appears as a good starting point for research and developing possible interventions. In the literature smoking behaviours has been found to be associated with many variables such as income and marital status (Fakuda, Nakamuk, Takano, 2005), work stress (Kouvonen, Kivinaki, Virtanen, and Vahtera, 2005), peer pressure ((Fergusson, Lynskey \& Horwood, 1995), parent employment, parent attitude, ethnicity, household size and gender (Barbosa, Carlini-Coltrin \& Silva-Filho, 1989; Muza et al., 1997; Horta, Calheiros, Pinheiro, Tomasi \& Amaral, 2001; Malcon et al., 2003; Altobelli et al., 2005; Ivanovic, Castro \& Ivanovic, 1997; Pinilla, González, Barber \& Santana, 2002), age (Ahmed, Brown, Gary \& Saadatmand, 1994; Barbosa et al., 1989; Ivanovic et al., 1997; Malcon et al., 2003; Muza et al., 1997), religiousity (Roff, Klemmack, Parker, Koening, SawyerBaker \& Allman, 2005; Leigh, Bowen \& Marlatt, 2005; Pirkle and Richter 2006) and schooling (Barbosa et al., 1989; Horta et al., 2001; Malcon et al., 2003; Pinilla et al. 2002; Leigh, et al. 2005).

Though smoking behaviour had been extensively examined in the western world as highlighted above, however it is important to find out what the situation is in other parts of the world. Western research had largely ignored other parts of the world especially events within the African setting thus justifying the need for this study.

In light of previous research and casual observations of the population under study, we hypothesized that smoking among young adults will be associated with (i) parenting styles, (ii) parental level of education, and (iii) influence of peers.

\section{METHOD}

\section{Participants}

The sample for this study was drawn from the student body of a large university in western Nigeria. All the 13 faculties in the university were represented in the survey due to the nature of the research. The sample consisted of 300 students in Part One. A total of 25 students each, identified by other students as smokers in their faculty and who consented to participate in the study were purposively selected for the study. Snowball sampling technique (whereby students help in the identification of student smokers) was adopted. This is because smoking openly is not done probably due to cultural and religious values. There are no written laws about this but it takes boldness for anyone to smoke openly during the day in the predominantly religious environment. Most smoking activities take place in the evenings, at parties and at certain places like drinking parlours, student union buildings and so on. This technique was therefore employed based on the above and the researchers' belief, that the student 
can easily identify their colleagues who smoke.

\section{Procedure and Instrument}

The researchers moved to other faculties once 25 smokers have been found in a faculty. Out of the 375 questionnaires obtained in all, only 300 were found useable. A self constructed questionnaire titled 'parenting style and adolescent smoking behaviour' (PSASB) was used to collect data. The instrument is divided into three sections. Section A elicited responses on respondents' demographic data. Section B determined the parenting style of the participants. Section $\mathrm{C}$ present questions on peers influence and smoking behaviour. The validity of the instrument was determined using expert judgement in the faculty and the reliability of the instrument was also determined using test retest method. A correlation coefficient of 0.75 was obtained which was deemed adequate for use for the study.

Data collected was analysed using simple percentages and chi-square analysis. All hypotheses are tested at 0.05 level of significance.

\section{RESULTS}

Two hundred and ten of the respondents were males while 90 were females, $70 \%$ and $30 \%$ respectively. One hundred and fifty nine of the respondents were between 16-19 years of age (53\%); 95 were between $20-24$ years $(31.7 \%)$ and 46 were between 25 and 29 years (15.3\%).

The first hypothesis stated that there would be a significant influence of parenting styles on smoking behaviour of adolescents and young adults. In testing this hypothesis, parenting style was classified into 4 categories, following Baumrind (1991): authoritarian, authoritative, permissive and uninvolved. The smoking behaviour was also determined according to smoking habits of low, moderate and high. Scores was then correlated with scores of respondents from parenting style scale. Table 2 presents the results. As the table indicates, 10,15 and 18 students with low, moderate and high smoking habits respectively experienced authoritarian parenting style. There were 31 low, 19 moderate and 97 high smokers that experienced authoritative parenting styles. For permissive parenting style, 27, 42 and 33 were low, moderate and high smokers respectively. 1 low, 2 moderate and 5 high smokers experienced uninvolved parenting styles. The chi-square analysis yielded a statistically significant influence of parenting style on smoking behaviour of students $X^{2}(6)=36.03, p<0.05$. The result showed that there is a significant influence of parenting style on smoking behaviour of students.

The second hypothesis stated that there would be a significant influence of parental level of education on smoking behaviour of students. To test this hypothesis parents were categorised into three groups which are no education, primary /secondary education and tertiary education. Chi-square analysis yielded a significant influence of parents' educational attainment on smoking behaviour $X^{2}(6)=60.40, p<$ .05 . Table 3 presents the more detailed results.

As Table 3 indicates, two students with low smoking habits, 5 with moderate and 11 high smokers are from parents with no education at all. There were 21 students with low, 29 moderate and 114 high smokers with parents who have primary to secondary education only. Forty six students with low smoking habits, 44 moderate and 28 high smokers are from parents with tertiary education. 
INFLUENCES ON SMOKING BEHAVIOUR OF ADOLESCENTS AND YOUNG ADULTS IN A NIGERIAN UNIVERSITY

Table 1: Social and demographic characteristics of sample $(\mathrm{N}=300)$

\begin{tabular}{|c|c|c|c|}
\hline Variables & & Number (n) & Percentage $(\%)$ \\
\hline \multirow[t]{2}{*}{ Sex } & Male & 210 & 70.0 \\
\hline & Female & 90 & 30.0 \\
\hline Total & & 300 & 100.0 \\
\hline \multirow[t]{3}{*}{ Age } & 16-19 years & 159 & 53.0 \\
\hline & $20-24$ years & 95 & 31.7 \\
\hline & 25-29 years & 46 & 15.3 \\
\hline Total & & 300 & 100.0 \\
\hline Fathers' Educational & None & - & - \\
\hline \multirow[t]{5}{*}{ Attainment } & Primary & 12 & 4.0 \\
\hline & Secondary & 102 & 34.0 \\
\hline & $\mathrm{NCE} / \mathrm{OND}$ & 92 & 30.7 \\
\hline & B.SC/HND & 84 & 28.0 \\
\hline & Postgraduate & 10 & 3.3 \\
\hline Total & & 300 & 100.0 \\
\hline Mothers'Educational & None & 18 & 6.0 \\
\hline \multirow[t]{5}{*}{ Attainment } & Primary & 22 & 7.3 \\
\hline & Secondary & 112 & 37.3 \\
\hline & *NCE/OND & 92 & 31.0 \\
\hline & *B.SC/HND & 53 & 17.0 \\
\hline & Postgraduate & 2 & 0.7 \\
\hline Total & & 300 & 100.0 \\
\hline
\end{tabular}

*NCE: National Certificate in Education, *OND: Ordinary National Diploma, *B.SC: Bachelor of Science degree, *HND: Higher National Diploma.

Table 2: Influence of parenting styles on smoking behaviour

\begin{tabular}{|c|c|c|c|c|c|c|c|c|}
\hline \multirow{2}{*}{ Parenting style } & \multicolumn{3}{|c|}{ Smoking Habits } & \multirow[t]{2}{*}{ Total } & \multirow{2}{*}{$\begin{array}{c}\mathrm{X}^{2} \\
\text { calc. }\end{array}$} & \multirow[t]{2}{*}{$\mathrm{X}^{2} \mathrm{tab}$} & \multirow[t]{2}{*}{$\mathrm{df}$} & \multirow{2}{*}{$\begin{array}{c}\mathrm{P}= \\
\text { value }\end{array}$} \\
\hline & Low & Moderate & High & & & & & \\
\hline Authoritarian & $\begin{array}{l}10 \\
(9.9 \%)\end{array}$ & $15(10.5 \%)$ & $\begin{array}{l}18 \\
(21.9 \%)\end{array}$ & 43 & & & & \\
\hline Authoritative & $\begin{array}{l}31 \\
(33.8 \%)\end{array}$ & $19(38.2 \%)$ & $97(75 \%)$ & 147 & & & & \\
\hline Permissive & $\begin{array}{l}27 \\
(23.5 \%)\end{array}$ & $42(26.5 \%)$ & $33(54 \%)$ & 102 & 36.03 & 12.59 & 6 & $\mathrm{P} \leq 0.05$ \\
\hline Uninvolved & $1(8 \%)$ & $2(2.1 \%)$ & $5(4.1 \%)$ & 8 & & & & \\
\hline Total & 69 & 78 & 153 & 300 & & & & \\
\hline
\end{tabular}


Table 3: Influence of parents' educational attainment and students' smoking behaviour

\begin{tabular}{|c|c|c|c|c|c|c|c|c|}
\hline \multirow{2}{*}{$\begin{array}{l}\text { Parents' } \\
\text { Educational } \\
\text { Attainment }\end{array}$} & \multicolumn{3}{|c|}{ Smoking Habits } & \multirow[t]{2}{*}{ Total } & \multirow{2}{*}{$\begin{array}{l}\mathrm{X}^{2} \\
\mathrm{cal}\end{array}$} & \multirow{2}{*}{$\begin{array}{l}\mathrm{X}^{2} \\
\mathrm{tab}\end{array}$} & \multirow[t]{2}{*}{$\mathrm{df}$} & \multirow[t]{2}{*}{$\overline{\mathrm{P}=\text { value }}$} \\
\hline & Low & Moderate & High & & & & & \\
\hline No Education & $2(4.1 \%)$ & $5(4.7 \%)$ & $11(9.2 \%)$ & 18 & & & & \\
\hline $\begin{array}{l}\text { Primary/ } \\
\text { Secondary }\end{array}$ & $21(37.7 \%)$ & $29(42.6 \%)$ & $114(83.6 \%)$ & 164 & & & & \\
\hline $\begin{array}{l}\text { Education } \\
\text { Tertiary } \\
\text { Education }\end{array}$ & $46(27.1 \%)$ & $44(30.7 \%)$ & $28(60.2 \%)$ & 118 & 60 & 12.59 & 6 & $\mathrm{P} \leq 0.05$ \\
\hline Total & 69 & 78 & 153 & 300 & & & & \\
\hline
\end{tabular}

The third hypothesis stated that there would be a significant influence of peers on smoking behaviour of adolescents and young adults. Chi-square analysis again yielded a significant effect of this variable $X^{2}(2)=19.97, p<.05$. As Table 4 indicates, students with low smoking habits had 24 smokers and 45 non smokers as peers. Smokers with moderate smoking habit had higher number of smokers as peers (46) while those with high smoking habits had 102 smokers as peers and only 51 peers as non smokers.

Table 4: Peers' influence on students' smoking behaviour

\begin{tabular}{|c|c|c|c|c|c|c|c|}
\hline \multirow{2}{*}{$\begin{array}{l}\text { Students' } \\
\text { Smoking } \\
\text { Behaviour }\end{array}$} & \multicolumn{2}{|c|}{ Peers } & \multirow[t]{2}{*}{ Total } & \multirow[t]{2}{*}{$\mathrm{X}^{2}$ cal } & \multirow{2}{*}{$\begin{array}{l}X^{2} \\
\text { tab }\end{array}$} & \multirow[t]{2}{*}{$\mathrm{df}$} & \multirow{2}{*}{$\begin{array}{c}\mathrm{P}= \\
\text { value }\end{array}$} \\
\hline & Smokers & Non-Smokers & & & & & \\
\hline Low & $24(39.6 \%)$ & $45(29.9 \%)$ & 69 & & & & \\
\hline Moderate & $46(44.7 \%)$ & $32(33.3 \%)$ & 78 & & & & \\
\hline High & $102(87.7 \% 0$ & $51(65.3 \%)$ & 153 & 19.97 & 5.99 & 2 & $\mathrm{P} \leq$ \\
\hline Total & 172 & 128 & 300 & & & & 0.05 \\
\hline
\end{tabular}

\section{DISCUSSION}

The results revealed that there was significant influence of parenting styles on smoking behaviour of adolescents and young adults. The highest number of smokers experienced authoritative parenting styles, followed by permissive then authoritarian while the uninvolved had the least. This result is inconsistent with what was found in literature. For instance, Simons-Morton, Haynie, Crump, Eitel, and Saylor (2001) findings, revealed that authoritative parenting protects against smoking and drinking.

From literature it is usually the adolescents from uninvolved parenting style that usually engage in high smoking habits and the least percentage of smokers are from permissive parents. This finding might have cultural undertone as authoritative parents are usually disciplinarians in Africa. As established in literature, the result of this style of parenting is that the children are usually quick to react and rarely get their parents to negotiate. Probably the smoking habits exhibited by students with this kind of parenting style might be a reaction to some of such disciplines.

Furthermore this study revealed that parents' educational attainment has significant influence on smoking behaviour of the participants. The 
findings reveal that the highest percentages of high smokers are from low educational attainment group of parents. This finding is consistent with the assertion of Shibata (1990), that parents with higher education who are in the upper class enjoyed affluent wealth and are able to brighten the educational frontiers of their children. So also those in middle class lived a moderate life while those who are poor could not meet up to the expectation of their children in terms of finances. Inadequate finances and low education are indices of social misbehaviour such as smoking.

The study also showed that adolescents and young adults can be influenced by their peers' smoking habits. This can be as a result of the flocking phenomenon where those who smoke can acquire friends that do smoke like them. A number of recommendations are emanating from this study. In the first instance, it is recommended that there should be increased parental enlightenment especially to parents with low educational attainment on how to help their children not to smoke. Secondly the influence of authoritative parenting styles on smoking need to be given wide publicity and parents encouraged to adopt appropriate parenting style. Other parents should be educated on appropriate parenting style to reduce the tendency of adolescents' and possibly young adults' engagement in smoking. Secondly, there should be school based prevention programmes and increased mass media public awareness. The programmes could include among others regular health talks about consequences and complications of smoking so that no matter the background children come from they are able to adopt healthy practices.

The findings of this research could have been influenced by the snowball sampling technique adopted in the methodology however this is not enough to invalidate the results as the use of this method is prompted by the prevailing cultural situation of the environment. Secondly some young adults included in the study might have implications for the results of this study. However they are still in part one and the information obtained from them can still be useful in designing intervention programmes for the level of students involved in the study. The age range of 25-29 years included in the study could be sources of the peer influence on the younger ones. This has not been determined therefore further studies would be needed in this area to confirm or refute this claim

\section{REFERENCES}

Ahmed F., Brown D. R., Gary L. E. \& Saadatmand F. (1994). Religious Predictors of Cigarette

Smoking: Findings for African American Women of Childbearing Age. Behavioral Medicine, 20, 34-43.

Alfred, G. G., Theodore, W. R., Alan, S. N., \& Palmer, T. (1990). The pharmacological Basis of Therapeutics, $8^{\text {th }}$ Ed. (pp. 545-47). New York: Pergamon Press.

Barbosa, M. T. S., Carlini-Coltrin, B. \& SilvaFilho, A. R. (1989). O uso de tabaco por estudantes de primeiro e segundo graus em dez capitais brasileiras: possíveis ontribuições da estatística multivariada para compreensão do fenômeno. Revista de Saúde Pública, 23, 401-409.

Baumrind, D. (1989). Rearing competent children. In W. Damon (ed)., Child development today and tomorrow. San Francisco: Jossey-Bass.

Blaize-Temple, D. and Kai Lo, S. (1992). Stages of drug use: a community survey of Perth teenagers. British Journal of Addiction, 87, 215-225.

Bothner, M.I.K., Mattsson, B., \& Fridlund, B. (2002). Influences on Adolescent Smoking 
Behaviour: Siblings' smoking and norms in the social environment do matter. Health and Social Care in the Community, 10, (4), 213-220.

Castrucci, B.C., \& Gerlach, K.K. (2006). Understanding the Association Between Authoritative Parenting and Adolescent Smoking. Maternal Child Health Journal, 10 (2): 217-224.

Chassin, L., Presson, C.C., Rose, J., Sherman, S.J., Davis, M.J. \& Gonzalez, J.L. (2005). Parenting Style and Smoking-Specific Parenting Practices as Predictors of Adolescent Smoking Onset. Journal of Pediatric Psychology, 30(4):333-344.

Darling, N. \& Steinberg, L. (1993). Parenting style as context. An Integrative Model. Psychological Bulletin. 113, 3487-496.

Fakuda, N., Nakamuk, K., \& Takano, T. (2005). Socio Economic Pattern of Smoking in Japan, income inequality, gender and age differences. Annals Epidemiology 15,365-372

Federal Ministry of Health (2000). Training Manual on Adolescent reproductive Health and Development. A publication of the Federal Government of Nigeria. Abuja.

Fergusson, D. M., Lynskey, M. T., \& Horwood, L. J. (1995). The Role of Peer Affiliations, Social, Family and Individual Factors in Continuities in Cigarette Smoking between Childhood and Adolescence. Addiction, 90, 647-659.

Hawkins, J.D., Catalano, R.F. \& Miller, J.Y. (1992). Risk and protective factors for alcohol and other drug problems in adolescence and early adulthood. Implications for substance abuse prevention. Psychological Bulletin, 112, 64-105.

Horta, B. L., Calheiros, P., Pinheiro, R. T., Tomasi, E. \& Amaral, K. C. (2001). Tabagismo em adolescentes de área urbana na região sul do Brasil. Revista de Saúde Pública, 25, 159-164.

Huxley, R. (2005). Successful parenting tip: Anger management for families. Parent survival.

$\mathrm{http} / / \mathrm{www}$.parentsurvival.org/blog/succes sful parenting/_archives/2005/9 (accessed 20/02/06).
Kandel, D.B. (1996). The Parental and Peer Context of Adolescent Deviance: An algebra of interpersonal influences. Journal of Drug Issues, 26, 289-315.

Karen, M. C., Brian, R. F., \& David, H. (1992). Why children start smoking cigarettes: predictors of onset. Addiction, 87 (12), 1711-1724.

Kouvonen A, Kivimeki M, Virtanen M, Pentti, J and Vahtera, J. (2005). work stress, smoking status and smoking intensity and observational study of 49,190 employees. Journal of Epidmology and community health 59, 63-69.

Leigh, J., Bowen, S. \& Marlatt, G. A. (2005). Spirituality, Mindfulness and Substance Abuse. Addictive Behaviors, 30, 1335 1341.

Malcon, M.C., Menezes, A.M.B., \& Chatkin, M. (2003). Prevalência e fatores de risco para tabagismo em adolescentes. Revista de Saúde Pública, 37, 1-7.

Merrill, J. C. (1994). Substance Abuse and Women on Welfare, New York: Center on Addiction and Substance Abuse at Columbia University.

Muza, G. M., Bettiol, H., Muccillo, G. \& Barbieri, M.A. (1997). Consumo de substâncias psicoativas por adolescentes escolares de Ribeirao Preto, SP (Brasil). I - Prevalência do consumo por sexo, idade e tipo de substância. Revista de Saúde Pública, 31, 21-29.

O'Byrne, K.K., Haddock, C.K. \& Poston, W.S. (2002). Parenting style and adolescent smoking. Journal of Adolescent Health, 30(6), 418-25.

Pinilla J., González, B., Barber P. \& Santana Y. (2002). Smoking in Young Adolescents: An Approach with Multilevel Discrete Choice Models. Journal of Epidemiology and Community Health, 56, 227-232.

Pirkle, E.C. \& Richter, L. (2006). Personality, Attitudinal and Behavioral Risk Profiles of Young Female Binge Drinkers and Smokers. The Journal of Adolescent Health: Official Publication of the Society for Adolescent Medicine, 38, 44-54.

Roff, L. L., Klemmack, D. L., Parker, M., Koening, H.G., Sawyer-Baker, P. \& 
Allman, R.M. (2005). Religiosity, Smoking, Exercise, and Obesity among Southern, Community-dwelling Older Adults. The Journal of Applied Gerontology, 24, 337-354.

Shibata, et al. (1990). Smoking Habits among Senior High School Students and Related Factors. Kurume Medline Journal. 37, 129-140.

Simons-Morton, B., Haynie, D.L., Crump, A.D., Eitel, P., \& Saylor, K.E. (2001). Effect of peer and parent influences on adolescent substance use. Health Education \& Behaviour, 28(1), 95-107.

Spears, S.F. \& Aker, R.L (1988). Social learning variables and the risk of habitual smoking among adolescents: The Muscatine study. American Journal of Preventive Medicine, 4, 336-342.

U.S National centre for Education Statistics (1999). The Condition of Education. NCES 199022.

Washington DC, US. Department of Education 